\title{
Personal Financial Management Practices of Secondary School Teachers in Kisii County: Kenya
}

\author{
Mary Bosire $^{1 *} \quad$ George Owuor $^{2} \quad$ Irene Asienga $^{3} \quad$ Fredrick Kalui $^{1}$ \\ 1.Department of Accounting, Finance and Management Science, Faculty of Commerce, Egerton University. P. O. \\ Box 536 - 20115, Egerton, Njoro, Kenya \\ 2.Department of Agricultural Economics and Agribusiness Management, Egerton University. P. O. Box $536-$ \\ 20115, Egerton, Njoro, Kenya \\ 3.Commission on Revenue Allocation. P. O. Box 1310-00200: Nairobi Kenya
}

\begin{abstract}
Personal financial management plays a critical role in enabling people make financial decisions that are important life shaping decisions. Failure to manage personal finances well leads to serious negative and long term consequences not only to individuals but also to enterprises and society. Studies have shown that there is a set of modern financial standard behaviors that are beneficial in managing personal finances and lead to financial success. These behaviors have been developed to a set of recommended financial practices that have been proved to positively influence financial decisions and promote responsible financial behavior. Even though personal finance experts and educators advocate for the use of these standard practices, research has shown that many people have not embraced their use. This study sought to establish whether secondary school teachers in Kisii County, Kenya use these recommended practices in managing their personal finances. A descriptive survey design was adopted and primary data collected using a questionnaire from a sample of 360 respondents. Data collected related to teachers' practices in saving, expenditure, investment and borrowing. Data was analyzed using percentages and mean scores. The findings revealed that $33 \%$ of the teachers sampled used the standard practices in managing their finances, $30 \%$ used the practices some of the times and $37 \%$ did not use the practices. The conclusion from the findings was that a high proportion of teachers $(67 \%)$ have not fully embraced the use of these standard practices in managing their personal finances. The implication was that many of the teachers are likely be facing challenges in their financial management. Either, they have not understood the importance of using the standard practices or there are probable underlying factors that influence their financial behavior. The study recommended that the Ministry of Education as the employer should implement workplace financial education or incorporate financial education in teacher training programmes to enable them understand and embrace the use of these standard financial practices for good financial management.
\end{abstract}

Keywords: Personal Financial Management Practices, Saving Practices, Expenditure Practices, Investment Practices, Debt Practices

DOI: $10.7176 /$ RJFA/10-6-09

Publication date:March $31^{\text {st }} 2019$

\section{Introduction}

Personal financial management has become increasingly important in today's world. This is because financial decisions are among the most important life shaping decisions that people make (Bimal, 2011; Chinen \& Endo, 2012). Joo (2008) describes personal financial management as a critical concept that allows people to control their financial situations and realize a feeling of financial security, create wealth and be in a state of financial well being. In his handbook on personal financial wellness, Joo (2008) pointed out that people ought to practice good financial management by building up healthy financial habits or practices. Garman and Forgue (2011) have highlighted the key issues in personal finance where individual apply principles and concepts of finance in making decisions that involve acquisition of financial resources, budgeting, saving, spending, insurance and investing. Other studies (Frasca, 2008; Kapoor, Dlabay \& Hughes, 2007) have highlighted personal finance as the management of monetary resources over time, considering various financial risks and potential life events. The main objective is to promote financial security and independence. Individuals who have the financial ability to make right decisions about their finances and live within their means are more likely to achieve financial success. The main objective of managing personal finances well is to create financial independence and improve living standards (Joo, 2008; Bimal, 2011).

Failure in managing personal finances can lead to serious long - term consequences not only for that person but also for enterprise, society (Falahati, Paim, Haron, Ismail \& Masud, 2011). The financial ability to make right choices about money and to live within financial means minimizes financial troubles, such as not making payments on time, being compulsive buyers, not saving for the future, not paying off credit cards in full each month and prioritizes spending according to needs (Chinen \& Endo, 2012). Traditionally, people have presented a set of financial management behaviors and beliefs based on the different ways money was handled in the family. In most cases, the significant family members who were decision makers on matters of money greatly 
influenced these individual behaviors (Hira, 1997). However with time, a new set of standard financial behaviors have been propagated by financial experts as best practices in managing ones personal finances (Godwin \& Carroll, 1986; Porter \& Garma, 1992; Joo \& Grabble, 2003; Behrman et al., 2012; Hira, 2012). However, research has also shown that many people have not understood and embraced the use of these practices (Dowling, Corney, \& Hoiles 2009; Rajna, Ezat, Syed \& Moshiri, 2011).

Further, research has shown that despite the existence of the set standard behaviors or practices that positively influence financial decisions, many people do not know how to manage their finances and consequently end up with financial frustrations characterized by issues such as overspending, over borrowing, a poor savings and investment culture (Rajna et al., 2011; Hilgert, Hogarth \& Beverly, 2003; Muske \& Winter, 2004; Dowling et al., 2009). In their study on financial management practices and money attitudes, Dowling et al., (2009) concluded that individuals and households are woefully unprepared and under informed in making financial decisions. Even though these conclusions may be based on samples from other regions, many Kenyans including those in formal employment like teachers also experience challenges in their financial management. Data from the Financial Sector Deepening (2009) showed that Kenyans have difficulties effectively implementing financial concepts in managing their personal finances and hence felt out of control of their finances. A report by the Institute of Economic Affairs (2016) indicated that an average Kenyan spends more than they earn exposing themselves to increasing debt. In view of this information, the underlying question that arises is whether Kenyans actually use the recommended financial practices when managing personal finances. Among these Kenyans are salaried employees with teachers are a significant proportion. This study sought to address this question by sampling secondary school teachers as a sub section of salaried employees and sought to establish the level to which they use the standard financial practices.

\subsection{Statement of the Problem}

Modern technology, financial innovations and societal financial expectations have made management of personal finances to be more complex and have greatly influenced people's financial decisions and behavior (Atheus, 2004). These complexities are a common trend in Kenya subjecting citizens to challenges in their financial decisions. Studies have shown that failure to manage personal finances well leads to serious negative and long term consequences to individuals and society (Joo, 2008; Falahati et al., 2011). Further, studies have also shown that many people do not know how to manage their personal finances (Dowling et al., 2009; Rajna et al., 2011). Consequently, they end up with financial frustrations which arise from over-indebtedness, overspending, unwise use of borrowed funds, bad spending decisions, poor money management and inadequate resources to make ends meet (Joo, 2008; Falahati et al., 2011). Issues such as not making payments on time, being compulsive buyers, not saving for the future, not paying off debt in full each period and on time, not prioritizing spending according to needs causes financial stress (Chinen \& Endo, 2012).

There are standard financial practices that have been proved to promote positive financial behavior (Porter \& Garman, 1992; Garman \& Forgue, 1994; Joo \& Grabble, 2003; Behrman, 2012; Hira, 2012). Personal finance experts and educators advocate for the use of these financial practices since they positively influence financial decisions. However, studies have also shown that these standard practices have not been fully understood and embraced by many people (Ameriks, Caplin \& Leahy, 2003; Muske \& Winter, 2004; Dowling et al., 2009; Rajna et al., 2011). Kenyans and among them teachers may not be an exception to this financial behavior. Evidence from a survey by FinAccess (2009) showed that many Kenyans lacked understanding of even basic financial concepts. They had difficulties in effectively implementing financial concepts in managing their personal finances and hence felt out of control of their finances. A report by Institute of Economic Affairs (2016) on household consumption rates in Kenya indicated that an average Kenyan spends more than they earn exposing themselves to increasing debt. These could be indicators of challenges or difficulties in managing personal finances. Among these Kenyans are salaried employees with teachers constituting a significant proportion. The underlying question that arises is whether Kenyans actually apply the advocated standard practices when managing personal finances. This study sought to address this question by sampling secondary school teachers as a sub section of salaried employees and sought to establish the level to which they use the set standard practices. While studies have documented personal financial management of employees from other sectors in the country and outside the region (Nyamute \& Maina, 2011; Asnake et al., 2015; Bahvani \& Shetty, 2017), there are no studies that have documented the personal financial practices of teachers in Kenya, and the extent to which they have embraced the standard financial practices advocated for use when managing of personal finances.

\subsection{Objective of the Study}

The objective of this study was to establish whether secondary school teachers in Kisii County use the standard financial practices in managing their personal finances. Specifically, the study sought to establish the use of the standard practices in managing saving, expenditure, investment and borrowing. 


\subsection{Justification of the Study}

This study sought to venture into a field that in critical in the development and improvement of the financial welfare of employees that are a key to National financial welfare and contribute to social welfare. Financial performance at individual and household level is a major component of National financial performance. In modern society, there is increasing recognition and concern for management of finances at personal and household level with a focus on improving social financial stability. An understanding of the concepts of financial practices of individuals is useful in designing national strategies on financial education in terms of the relevant practices to be considered.

Secondly, employers' interest on their employees' financial stability and independency has increased due to the need to improve productivity and lower employee costs. Hence, it is in the best interest of employers to focus on their workers' personal financial problems as they have a direct bearing on workplace productivity. The findings of this study would be useful to the government as an employer, the Teachers Service Commission, personal finance experts and educators and other key stakeholders in formulating policies and approaches to help teachers effectively manage their financial resources with a focus on improving productivity and reducing employees' financial stress. The findings would also contribute greatly to the development and implementation of employee financial education programmes.

\section{Review of Literature}

Personal financial management has become increasingly important in today's world. Deacon and Firebaugh (1988) defined personal financial management as the set of behaviors performed regarding the planning, implementation and evaluation that is involved in the management of one's financial resources. A more recent definition by Xiao and Dew (2011) takes into account personal financial management with respect to the management of cash flow, credit, saving and investment. For individuals, a good spending culture, paying debt, planning for retirement, having active savings and investments are key components of financial goals to be achieved through financial management (Joo \& Grabble, 2003). Globalizations, technological and economic changes that are difficult to predict have created the ever increasing need for people to manage their personal finances. These changes influence the financial behavior of individuals and their approach to personal financial management. Among the main components of personal financial management is the management of one's savings, expenditure, investments and debt (Kapoor et al, 2007). Hence, the importance of personal financial management cannot be underestimated since it enables individuals improve the standard of living, which leads to good health and financial stress reduces.

Kapoor et al., (2007) have described personal finance management as a process of continuous management of money, consisting of activities related to the preparation and implementation of monetary operations. The main areas of personal financial management include: generating income, spending, savings, investing, lending/borrowing, risk management, retirement planning, tax planning and wealth transfer (Beal \& McKeown, 2003; Callaghan et al., 2012; Kapoor et al., 2007). Effective financial management behavior should improve financial well-being positively and failure to manage personal finances can lead to serious long term, negative social and societal consequences (Joo, 2008). Failure in managing an individual's finance can lead to serious long term consequences not only for that person but also for enterprise, society (Ismail et al., 2011).

\subsection{Personal Financial Management Practices}

It is a fact that money plays a vital role in people's lives, but how to handle the money properly is more important. Financial decisions are among the most important life shaping decisions that people make and these decisions are behavioral in nature. Kwok, Milevisky and Robinson (1994) defines personal finance management practices as a set of standard behaviors by individual or families that is beneficial in managing finances in order to achieve a satisfactory status in terms of expected financial goals. The advent of modern financial environment presents a wide range of innovative systems, products, services and information that influences financial decisions behaviors to new and modern financial standard behaviors (Behrman et al., 2012). Research shows that the standard financial practices have been developed to a set of recommended personal financial management practices that have been empirically tested and proofed to positively influence financial decision making process (Behrman et al., 2012; Hira,2012). When these standard practices are adopted by individuals and households, they lead to the achievement of high levels of income, low debt, a good spending culture, active savings and investment (Porter \& Garman, 1992; Garman \& Forgue, 1994; Joo \& Grabble, 2003).

Personal financial management textbooks, non formal personal finance curricula, such as Money 2000 (New Jersey Cooperative Extension, 1996), popular press books on personal finance, and financial management workshops offer a core set of concepts or recommended financial practices which positively influence financial decisions. It is suggested that, if the practices are followed, the individual and/or family will achieve financial success/goals (Joo \& Grabble, 2003; Behrman, et al., 2012; Hira, 2012) . The recommended practices being advocated for today can be traced back to early personal financial management textbooks (Andrews, 1935; 
Hanson \& Cohen, 1954).

For years, personal finance experts and educators have advocated for the use of a set of standard practices for managing personal finances (Hanson \& Cohen, 1954; Rettig \& Mortenson, 1986; Key, Starfod \& Dickson, 1989; Garman \& Forgue, 1994). While these recommended practices have evolved over time, the prime objectives they serve remains the same. Modern personal finance textbooks document standard practices in the financial domains of cash flow management, expenditure, savings, insurance, retirement planning, tax planning and investment (Frasca, 2008; Garman \& Forgue, 2011). The practices include making budgets, setting financial goals, managing debt, monitoring and controlling expenditure, keeping financial records, making savings and investment.

Research findings have established that individuals' positive financial management practices have been proofed to be the most significant influential determinant of financial satisfaction and stability (Joo and Grabble, 2004). This implies that financial management practices are the most significant determinant of financial success. Failure in managing an individual's personal finances leads to serious long term consequences to the person and society (Fahalati et al., 2011). Adoption of the standard financial practices is a behavioral practice by the users which is influenced by other factors. Ameriks et al., (2003) in a study on wealth accumulation and the propensity to plan analyzed why similar households end up having different levels of wealth. The study established that attitudes and skills in approaching financial planning were very significant in influencing individual and household wealth accumulation. Households who had a higher propensity to plan their finances also had higher levels of wealth accrued since such households were careful in spending and more proactive in savings and investment. However, Dowling et al., (2009) in a study on financial management practices and money attitudes concluded that individuals and households are woefully unprepared and under informed in making financial decisions.

Personal financial practices are contingent to the person's financial capability. Collins, Zollman and Maina (2009) in the Financial Sector Deepening research on financial capability in Kenya characterized financially capable people as the ones who are resilient to changing financial needs. They contended that the practices of financially capable people are less vulnerable to using or overusing products that do not meet their needs. They know, for example, how to balance credit and savings, how much insurance they need and how to structure their financial tools to meet their goals. They have better welfare outcomes, because they make savvy financial decisions that help them realize their investment and savings goals protect their assets, and smooth consumption (Collins et al., 2009). Policymakers, practitioners, and financial institutions have responded with a proliferation of financial education programs which cover topics such as basic numeracy, spending, planning, budgeting, incomes, credit, debt, bill paying, saving, and managing financial risk, investing, or taxes. According to Kloeppinger-Tood and Sharma (2010), the core of a financial education agenda must include budgeting, savings, investment and managing debt.

Hilgert et al., (2003) in a study on Household Financial Management looked at the connection between knowledge and behavior by examining household financial management practices among American households. The study used four types of financial practices which included cash - flow management, credit management, savings and investment management. A computed index for each of the practices was used to determine whether each of the practices was low practice, medium or high practice. The conclusions was that while a majority households reported good cash flow management practice and had savings accounts, a small percent used spending plans or budgets and saved for long term goals. At the same time a small percent reported investing in financial instruments like stocks.

Rajna et al., (2011) in a study on financial management attitudes and practices among medical practitioners in Malaysia confirmed that the medical practitioners learned money management by trial and error and often made financial mistakes. The study analyzed the doctors' personal finance management trends, strengths and weaknesses. The study results indicated that even though the practitioners had a high financial management attitude very few of them practiced favourable money management practices.

Malewos and Abiy (2015) studied personal finance management capabilities among employees in the formal sector in Jimma town in Ethiopia and collected primary data on their financial practices. The financial management capabilities were based on the decisions made in terms of savings, credit, insurance, investment and debt. The basis argument for the study was that due to the increasing complexity in financial systems, increasing access to credit and the high cost of living in the modern environment created the need for individuals to employ personal finance management practices in order to live a healthy financial life. The findings from this study established that the formal sector employees were not using suggested best financial practices in managing their personal finances. The study also established that the financial management practices did not vary across employees of different cadres or different organizations

From the reviewed literature, personal financial management has been discussed as an important concept in today's world since it enables people achieve financial success/goals (Joo \& Grabble, 2003; Joo, 2008, Beal \& McKeown, 2003; Kapoor et al., 2007; Garman \& Forgue; Xiao \& Dew, 2011). At the same time, research has 
evidenced that there are a set of financial practices that have been developed over time and are recommended for use in managing personal finances. These recommended practices have been proved to positively influence financial decisions and promote a responsive financial behavior (Godwin \& Carroll, 1986; Porter \& Garma, 1992; Joo \& Grabble, 2003; Behrman, 2012; Hira, 2012). While these standard practices have been advocated for use, research also shows that many people do not actually implement these practices and hence face challenges in managing their personal finances (Ameriks et al., 2003; Muske \& Winter, 2004; Dowling et al., 2009; Rajna et al., 2011). The basis argument of this study was that the advent of the modern financial environment and technology has made the management of personal finances to be more complex and have greatly influenced people's financial decisions and behavior (Atheus, 2004). This creates a need for Kenyans and more specifically salaried employees to understand and embrace good personal financial practices in order to achieve financial success/goals. In view of the above reviewed literature, this study sought to establish whether secondary school teachers who are a sub section of salaried employees use the standard financial practices.

\section{Methodology}

This study adopted a descriptive survey design since the aim was to describe and document aspects of teachers' financial practices the way they were. Information was collected from the sampled respondents without changing the environment. Aspects of teachers' practices in saving, expenditure, investment and debt management were documented. Data was collected and analyzed for fact finding. The study was conducted in Kisii County, Kenya. A representative sample of 360 respondents was randomly selected from a sampling frame of 3615 teachers using the formula by Yamane (1967) and a questionnaire administered to collect primary data. However, out of the 360 teachers sampled, those who filled and returned the questionnaire were 313 , representing about $87 \%$ response rate.

The questionnaire contained 35 questions which were divided into 4 sections based on the four domains of financial practices that were considered in the study. These included practice in saving, expenditure, investment and debt. There were eight response items on Saving practice, ten on expenditure practice, nine on investment practice, and eight on debt practice. The financial practices of teachers were examined using a modified version of the financial behavior measures employed by Joo and Grable (2004) and items in the financial behaviour measure scale designed and developed by Xiao and Dew (2011). The modified scale comprised of 5-point likert scored from (1) which meant the practice was never done to (5) which implied the practice was always done. The phrasing of the questions was tailor made to make the instrument suitable for independent administration. Higher scores indicated the financial practice was being used while low scores indicated the practice was not being used. The respondents were asked to rate themselves on the score range from 1 to 5 on different items under savings practice, expenditure practice, investment practice and debt practice.

Data was analyzed using descriptive statistics. For purposes of establishing the level of use of the practices, three response categories were formed which included poorly practiced, fairly practiced and good practice. Low scores of 1 and 2 on a practice were considered that the practice was poorly used, a score of 3 was considered as fairly used and high scores of 4 and 5 meant good use of the practice. Data was presented using percentages and mean score summary tables. The percents and mean scores were manually tabulated and used to interpret the respondents' use of the practices.

\section{Results and Discussion}

The main objective of this study was to establish whether secondary school teachers in Kisii County use the standard financial practices recommended for managing personal finances. Standard financial practices in saving, expenditure, investment and borrowing were used. Descriptive analysis was applied. Results and discussions are presented in Table 1 to Table 4.

\subsection{Results on Saving Practices}

The study sought to find out whether teachers made regular savings, saved for long term and short term goals, maintained special saving accounts, increased savings with income increases, saved in high interest accounts and saved for retirement. Eight response items were used to measure saving practices. The results are presented in Table 1. 
Table 1.

Distribution of Responses on Teachers Use of Savings Practices per Category $(N=313)$

\begin{tabular}{lccc}
\hline Savings Practice Items & $\begin{array}{c}\text { Poor Used } \\
(\%)\end{array}$ & $\begin{array}{c}\text { Fairly Used } \\
(\%)\end{array}$ & $\begin{array}{c}\text { Good Use } \\
(\%)\end{array}$ \\
\hline Making consistent and regular & 29.7 & 34.5 & 35.8 \\
Saving for Long Term Goals & 30.7 & 30.7 & 38.7 \\
Saving for Short Term Goals & 26.5 & 32.2 & 41.2 \\
Saving From Each Income Received & 40.9 & 30.0 & 29.0 \\
Maintaining Special Savings Accounts & 54.0 & 19.8 & 26.2 \\
Increases Savings with income increases & 39.9 & 28.1 & 31.9 \\
Saving in High Interest Accounts & 66.4 & 21.7 & 11.8 \\
Saving for Retirement & 28.8 & 9.6 & 61.7 \\
\hline Mean Score (\%) & $\mathbf{3 9 . 6}$ & $\mathbf{2 5 . 8}$ & $\mathbf{3 4 . 6}$ \\
\hline
\end{tabular}

From the results in Table 1, the mean scores per category indicated how the respondents had embraced the use of the savings practices. The results indicate that $39.6 \%$ of the teachers did not use the practices, $25.8 \%$ fairly used the practices and $34.6 \%$ used the practices in their saving management. This implied that a majority of the teachers $(65.4 \%)$ had not embraced the use of the saving practices indicated. A comparison between the poor, fair and good use categories showed that most practice items recorded less than $50 \%$ response rate under the good use category except for saving for retirement (61.7\%). While a significant proportion indicated that they use the practices some of the times $(25.8 \%)$, this was considered not good enough if the objectives of good saving management has to be achieved. From the results, it was evident that most of the teachers do not maintain special savings accounts (54\%) and do not save in high interest earning accounts $(66.4 \%)$.

Developing good saving habits is considered important in enabling individuals create a good savings culture. These results on the use of the standard saving practices are consistent with data in the World Bank Report (2016) on Kenya's country economic memorandum which indicated that Kenyans have a high spending culture at the expense of making saving. Only $35.8 \%$ of the teachers indicated they made regular and consistent savings while only $29 \%$ saved from each income they received. A significant number $(39.9 \%)$ never increased savings whenever their incomes increased. The implication is that more of their salary increments could be directed to consumption. Further, findings from a survey done by the Kenya savings and investment monitor on the current savings behaviour of employees in Kenya indicated that Kenyan employees are saving less compared to what they used to save in previous years (Kenya Savings and Investment Monitor Annual Survey report on Kenyan Workers, 2016). There is a likelihood that not embracing the standard savings practices is a contributory factor to such outcomes. The behavioral life - cycle hypothesis on savings argues that savings requires effort and self control. This is because individuals are often tempted to spend instead of saving (Modigliani \& Brumberg, 1954). This justifies the need for the entrenchment of a culture of savings by employees in Kenya.

\subsection{Results on Expenditure Practices}

This study sought to establish whether the respondents use the standard expenditure practices when managing their spending. This involved finding out whether they made budgets, spend within their means, avoided impulse or unplanned spending, were prepared for emergencies, kept financial records and compared prices before making major purchases. Nine items were used to measure the expenditure practice. Results are presented in Table 2.

Table 2.

Distribution of Responses on Teachers Use of Expenditure Practices per Category (N=313)

\begin{tabular}{lccc}
\hline Expenditure Practice Items & $\begin{array}{c}\text { Poorly Used } \\
(\mathbf{\%})\end{array}$ & $\begin{array}{c}\text { Fairly Used } \\
(\%)\end{array}$ & $\begin{array}{c}\text { Good Use } \\
(\%)\end{array}$ \\
\hline Making a budget before spending & 25.6 & 27.2 & 47.2 \\
Always using budget when spending & 27.2 & 39.0 & 33.8 \\
Spending not exceeding income & 30.0 & 31.3 & 38.7 \\
Avoiding unplanned spending & 36.4 & 32.6 & 31.0 \\
Keeping Enough Money for Expenses & 32.9 & 37.1 & 30.0 \\
Expenditure not Exceeding Planned & 31.6 & 34.5 & 33.9 \\
Keeping Emergency Fund & 39.9 & 38.0 & 22.1 \\
Keeping Financial Records & 40.6 & 40.9 & 18.6 \\
Comparing prices before major purchases & 30.6 & 48.9 & 20.5 \\
\hline Mean Score & $\mathbf{3 2 . 2}$ & $\mathbf{3 3 . 7}$ & $\mathbf{3 4 . 1}$ \\
\hline
\end{tabular}

From the mean score results in Table 2, only $34.1 \%$ of the respondents were in the good use category implying they used the standard expenditure practices, $33.7 \%$ were in the fairly used category meaning they sometimes use the practices and $32.2 \%$ did not or rarely used the practices. All the expenditure practice items 
recorded a response rate of below $50 \%$ in the good use category. Budgets are regarded as the financial plan that balances income and expenditure ((Dew \& Xiao, 2011). From the results, a significant number of the teachers $(47.2 \%)$ were found to have good practice of making a budget before spending. However, the response scores on those who used the budget every time before spending was lower (33.8\%). This implied that while a significant number were able to make a budget, not all could stick to the budget when spending. The result corresponds with the proportion of teachers $(36.4 \%)$ that are not able to avoid impulse or unplanned spending. It is easier to make a budget but executing the budget requires self control.

A comparative analysis of the results between scores in the good use category with those in the poorly used category, showed that $39.9 \%$ of the teachers did not keep emergency funds, $40.6 \%$ did not keep financial records, $36.4 \%$ did not avoid impulse spending and $30.6 \%$ never made price comparisons before making major purchase. On the other hand, a higher proportion of teachers were good in making budgets before spending (47.2\%), spend within their incomes $(38.7 \%)$, spend what was planned for $(33.9 \%)$ and used a budget $(33.8 \%)$. It was notable that very few teachers were good in keeping financial records $(18.6 \%)$, comparing prices before making major purchases $(20.5 \%)$ and keeping emergency funds $(22.1 \%)$.

Financial experts advocate for best practices in the management of spending as a means to good financial health (Xiao \& Dew, 2011). A report by the National Foundation for Credit Counseling (2007), indicates that many financial experts agree and emphasize that making a budget before spending and sticking to the budget creates better spending habits. Budgets enable users avoid the tendency of extravagant spending which leads to huge debt burdens. Individuals are able to spend within their means and avoid making impulse expenditure (Xiao $\&$ Dew, 2011). From the results on the spending practices, it is notable that while a significant proportion make a budget, many of these teachers did not always use the budget. This could be a probable explanation to why many of them are not have good practice in the other expenditure practice items.

\subsection{Results on Investment Practices}

This study sought to establish whether teachers use the standard investment practices in terms of periodic preparation and implementation of investment plans, having investment goals, investment evaluation and selection, investing in real estate and in financial assets. Nine items were used to measure the investment practices. The results are presented in Table 3 .

Table. 3

Distribution of Responses on Teachers Use of Investment Practices per Category (N=313)

\begin{tabular}{|c|c|c|c|}
\hline Investment Practice Items & $\begin{array}{l}\text { Poorly Used } \\
\%\end{array}$ & $\begin{array}{l}\text { Fairly Used } \\
\%\end{array}$ & $\begin{array}{l}\text { Good Use } \\
\%\end{array}$ \\
\hline Having Annual Investment Plans & 41.2 & 25.9 & 32.9 \\
\hline Effecting Investment Plans & 35.8 & 37.4 & 26.8 \\
\hline Achieving Investment goals & 38.0 & 49.5 & 12.5 \\
\hline Investment Analysis Before Implementation & 34.9 & 29.1 & 36.1 \\
\hline Periodic Evaluation of Investments Held & 39.6 & 29.1 & 31.4 \\
\hline Holding High Income Investments & 59.5 & 31.0 & 9.6 \\
\hline Asset Value Exceeds Liabilities Value & 46.6 & 27.2 & 26.2 \\
\hline Investing in Real Estate & 77.4 & 19.8 & 2.9 \\
\hline Investing in Financial Instruments & 45.7 & 16.9 & 36.3 \\
\hline Mean Scores & 46.5 & 29.5 & 23.9 \\
\hline
\end{tabular}

From the results in Table 3, the mean scores indicate that there were more teachers $(46.5 \%)$ who did not use the standard investment practices compared to those who fairly used $(29.5 \%)$ and those who used $(23.9 \%)$ the practices to manage their investments. A general observations of the scores between the good use category and the poor use category showed that more teachers were in the poor use category in most practice items except for the practice of doing investment analysis before implementation. This implied that a majority of the teachers did not apply standard investment practices in managing investment. Investment in real properties recorded the highest response rate $(77.4 \%)$ as being poorly done. Most teachers did not seem to invest in real estate and $59.5 \%$ did not hold high income investments. These two practices, together with the practice of achieving investment goals had the lowest proportions of responses in the good use category $2.9 \%, 9.6 \%$ and $12.5 \%$ respectively. It was also evident that more teachers (46.6\%) did not have asset values of their investments that exceeded their liabilities, did not achieve investment goals $(38.0 \%)$, did not do periodic evaluation of investments held $(39.6 \%)$ and did not invest in financial instruments $(45.7 \%)$.

Investment is an important ingredient in personal financial management. Investments create additional sources of income that ensure regular funds to meet ones financial obligations (Daiva \& Audra, 2017). When planning for personal finances, people often want to grow their surplus money by saving part of it and investing part of it (Reilly \& Brown, 2006). Adopting a good investment culture determines the achievement of investment goals. Investment professionals advocate that among the best practices in investment include making investment 
plans, monitoring and evaluating investments held.

\subsection{Results on Debt Practices}

This study sought to establish whether teachers applied the standard debt practices in managing borrowing. These included finding out whether they paid their debts on time and in full, avoided or minimized taking emergency loans, having good credit history, avoiding over borrowing and avoiding taking advances to pay debts. Eight items were used to measure the practices of teachers in their debt management. The results are presented in Table 4.

\section{Table. 4}

Distribution of Responses on Teachers use Debt Practices per Category $(N=313)$

\begin{tabular}{lccc}
\hline Debt Practice Items & $\begin{array}{c}\text { Poorly Used } \\
(\%)\end{array}$ & $\begin{array}{c}\text { Fairly Used } \\
(\%)\end{array}$ & $\begin{array}{c}\text { Good Use } \\
(\%)\end{array}$ \\
\hline Paying Debts on Time & 10.9 & 22.4 & 66.8 \\
Paying Debts in Full when Due & 24.6 & 38.3 & 37.1 \\
Avoiding/Minimizing Emergency Loans & 38.3 & 39.3 & 22.3 \\
Using Borrowed Funds for Investment & 24.9 & 51.8 & 23.3 \\
Not Taking Advances to Pay Debts & 37.3 & 28.1 & 37.5 \\
Having a Good Credit History & 41.5 & 20.8 & 37.7 \\
Avoiding Over borrowing & 40.9 & 24.0 & 35.1 \\
No Penalty Charges for Delayed Payments & 17.6 & 22.7 & 59.8 \\
\hline Mean Scores & $\mathbf{2 9 . 5}$ & $\mathbf{3 0 . 9}$ & $\mathbf{3 9 . 6}$ \\
\hline
\end{tabular}

From the results in Table 4, the results showed that three practice items recorded higher responses in the good use category compared to those in the poorly used category. A higher proportion of teachers $(66.8 \%)$ were good in paying debts on time. This was evidenced also by a bigger proportion $(59.8 \%)$ who always avoided being charged penalties for paying debts late. The results also indicated that $40.9 \%$ were not avoiding over borrowing, those who did not have a good credit history (41.5\%) while those who could not avoid emergence loans $(38.3 \%)$. The overall mean scores gave an impression that there were a significant number of teachers (39.6\%) who used the standard practices in the management of debt compared to those who did not $(29.5 \%)$. These results are supported by findings on debt management from annual survey by the Kenya savings and investment monitor on Kenya's employee savings and investment behavior (2016). From the Survey results, $74 \%$ of those employees interviewed indicated they avoided over borrowing. However, the result did not indicate whether this was the case always.

Debt is often associated with high interest rates or fees, which can lead to financial distress or financial struggles if not managed properly (Lusardi \& Tufano, 2015). Having large amounts of high interest debt hurts one's ability to save or invest and meet other needs. However, personal financial advisors argue that debt is a fact of life for people and can be a convenient way of making purchases now and paying for them over extended periods of time. But when debt is not managed well, it becomes a burden and causes financial hardship. The changing financial environment has created easy credit accessibility where more people are finding themselves tangled up in huge amounts of debt much of which is consumer debt. From the result, the proportion of teachers who always used borrowed funds for investment was low (23.3\%) implying more of the borrowed funds are being directed to consumption.

\subsection{Results on Financial Management Practices}

A summary of the mean score responses per category in each financial practice domain are presented in Table 5 Table 5

Mean Score Responses on Teachers Use of Financial Practices per Category ( $N=313)$

\begin{tabular}{lccc} 
Mean Score Responses on Teachers Use of & Financial Practices per Category $(\boldsymbol{N}=313)$ & \\
\hline & Poorly Used & Fairly Used & Good Use \\
Financial Management Practices & $\%$ & $\%$ & $\%$ \\
\hline Savings Management Practices & 39.6 & 25.8 & 34.6 \\
Expenditure Management Practices & 32.2 & 33.7 & 34.1 \\
Investment Management Practices & 46.5 & 29.5 & 23.9 \\
Debt Management Practices & 29.5 & 30.9 & 39.6 \\
\hline Mean Score & $\mathbf{3 6 . 9 5}$ & $\mathbf{2 9 . 9 8}$ & $\mathbf{3 3 . 0 7}$ \\
\hline
\end{tabular}

\section{Source: Research Data; 2018}

The results in Table 5 show the summary analysis of how secondary school teachers in Kisii County use the standard financial practices across the four financial domains of saving, expenditure, investment and debt. A comparative view of the results indicate that investment practices had the highest mean score $(46.5 \%)$ for not being used followed by savings practices $(39.6 \%)$. This implies that more teachers have not embraced the 
standard savings and investment practices compared to those who used the practices some of the times or always used the practices. The practice of debt management had a higher mean score $(39.6 \%)$ in the good use category. It is notable from these findings that in all the four financial practice domains, the proportion of respondents in the good use category is below $40 \%$. These results conform with the behavioral hierarchy of allocating incomes where paying of expenses and loan payments take precedence over other types of financial obligations like savings and investment (Hilgerth \& Hogarth, 2003). For debt management, these results could likely be attributed to credit controls by the lenders and employers where loan repayments are remitted from the source through the check off system and the lenders credit assessment procedures on credit worthiness of borrowers.

The aggregate mean scores for the financial practices indicate that $36.95 \% \%$ of the teachers have not embraced the standard practices in managing their personal finances while $33.7 \%$ have fully embraced good financial practice. $29.98 \%$ have fairly embraced the standard practices. This calls for concerns about the personal financial management of these teachers since a higher proportion $(66.93 \%)$ have not fully embraced the financial practices advocated for good management of their personal finances

\subsection{Discussion of Results}

The objective of this study focused on finding out whether secondary school teachers in Kisii County use the advocated standard financial practices in managing their saving, expenditure, investment and borrowing. These practices have been proved to positively influence peoples financial behavior (Joo \& Grabble, 2003; Behrman, et al., 2012; Hira, 2012). The overall mean results showed that only 33\% of the teachers sampled have fully embraced these standard practices in managing their personal finances. Even though $(30 \%)$ of the teachers had indicated that they sometimes apply the practices, it was considered not good enough if the desired results of achieving financial well being is to be realized. Teachers who rarely or never use these standard practices were the majority (37\%). These result are consistent with research findings that have established a disconnect between the standard practices and why they were not being used (Rajna et, al, 2011; Malewos \& Abiy, 2015). A study on the financial management practices of the medical practitioners in Malaysia found out that very few of the sampled doctors practiced favourable money management practices (Rajna et al., 2011). Malewos and Abiy (2015) looked at the financial management of employees in Ethiopia and found out that these employees were not using suggested best practices in managing their personal finances. More related studies have documented similar concerns that these standard practices have not been embraced (Ameriks et al., 2003; Muske, Osteen, \& Jones, 2007; Dowling et al., 2009).

The saving practice $(39.6 \%)$ and investment practice $(46.5 \%)$ recorded higher proportions of respondents that do not use the standard practices. This results show consistency to the general saving, consumption and investment culture by Kenyans (World Bank Report, 2016). The report indicates that Kenya's household savings is low compared to other economies in the region and this has a negative effect on investment in the country and hence affecting economic growth. The poor savings and investment practice culture is a likely indicator that instead of savings, many of the teachers are spending a big percent of their incomes and even rely on loans as a source of money to spend.

There could be possible explanations for these kinds of results on teachers' financial practices in a Kenyan environment. Behavioral finance theories explain people's behavior in financial settings. The behavioral aspects to financial decision making process could explain the fundamental causes of the kind of financial behavior by teachers in embracing the financial practices. However, this may need to be investigated and documented. Personality traits, demographic characteristics, socioeconomic factors, cognitive and emotional biases are believed to determine peoples financial phenomena (Sunitha, 2012). Common characteristics like lack of self control, limited cognitive abilities and inertia are known to shape financial behavior and can only be subjectively attributed to such results on teachers' adoption of the standard financial practices.

\section{Conclusion}

Financial problems resulting from poor personal financial management is known to cause financial stress and affect individual productivity at the workplace. These financial problems include over-indebtedness, overspending, unwise use of borrowed funds, bad spending decisions, poor money management and inadequate resources to make ends meet. In this study, the financial practices tested the ability of positive responsive financial behavior of the teachers in managing their personal finances on four key area of personal finance. The findings from this study revealed that many of the teachers $(67 \%)$ have not wholly embraced the use of the standard practices recommended in managing their personal finances. Based on the findings, only $33.07 \%$ of the teachers were found to have fully embraced the use of the standard practices in their financial management. This implies that many of them could be facing challenges in their financial management. It is probable that a majority of them have not understood the importance of using these standard practices or they lack the financial capability to apply the practices or there could be other underlying constraints to the use of these practices 


\subsection{Recommendations}

Based on the finding and implications, this study recommends government intervention and policy that empowers teachers with personal financial management capabilities to enable them understand the importance of embracing the set standard financial practices. Specifically, there is need for the entrenchment of a culture of savings and investment for teachers in Kenya through the introduction of work place financial education and incorporation of personal finance education in teacher training programmes. The government through the ministry of education should consider working in partnership with personal financial experts and educators to develop the training programmes. Financial education for teachers in Kenya would also ensure future generations embrace good financial management since teachers are at the core of information dissemination in institutions of learning.

\subsection{Recommendations for Further Research}

The scope of this study was confined to only establishing whether the teachers sampled used the standard practices in managing their personal finances. The financial practices that were used as measures are linked to promoting responsible financial behavior with the objective of achieving favourable financial outcomes which can be in terms of financial success, well being, stability or independence among others. While the findings from this study have shown that a majority of the teachers $(67 \%)$ have not fully embraced the use of the standard practices, their actual financial position was not considered as dependent on the practices. Hence, this study recommends for further research to include data on the teachers financial position as a dependent variable on their practices to validate whether the recommended practices actually create positive financial outcomes or not. Secondly, results from this study have shown that a majority of the sampled teachers have not embraced the standard practices in managing their personal finances. However, the determinants of their financial behavior were not investigated. This study could be replicated with a focus of establishing the determinant factors that have caused many of these teachers not to embrace these advocated practices.

\section{References}

Aime, D, P., \& Cohart, J. (2014). Work Place Financial Education Facilitates Improvement in Personal Financial Behaviors. Journal of Financial Counceling and Planning, 25(1), 5 - 26

Ameriks, J., Caplin, A., \& Leahy, J. (2003). Wealth Accumulation and Propensity to Plan. The quarterly Journal of Economics, 118 (3), 1007 - 1047

Atheus, W. L. (2004). Financial Illiteracy in America; A Perfect Storm, A Perfect Opportunity. Journal of Financial Service Professionals, 58(6), 49 - 56

Beal, D., \& McKeown, W. (2003). Personal Finance. Milton: John Wiley and Sons

Behrman, J. R., Mitchell, O., Soo, C., \& Bravo, D. (2012). How Financial Literacy Affects Household Wealth Accumulation. American Economic Review, 102 (3), 300 - 304

Bimal, B. (2011). Financial Management Importance. (From)http://www.blognbuzz.com/financial-managementimportance.html. Retrieved 12 April 2017.

Callaghan, G., Fribbance, I., \& Higgison, M. (2012). Personal Finance. Palgrave McMillan New York

Chinen K. \& Endo, H. (2012) Effects of Attitude and Background on Personal Financial Ability: A Student Survey in the United States, International Journal of Management, 29 (1), 33-45.

Collins, D., Zollman, J., \& Maina, B. (2009). Financial capability in Kenya. Nairobi, Kenya: FSD Kenya.

County Education Office, Kisii, (2015). Teachers Records. Unpublished document

Daiva, D. G., \& Audra, V. (2017). The Importance of Personal Finance for Investment. Applying Financial Behavior Principles in Personal Finance Investment Decisions. Research Journal of Societal Studies, 8(1), $118-131$

Deacon, R.E., \& Firebaugh, F. M. (1988). Systematic Family resource management: Principles and applications, Toronto: Allyn \& Bacon.

Dowling, A., Corney, T., \& Hoiles, L. (2009). Financial Management Practices and Money Attitudes as Determinants of Financial Problems and Dissatisfaction in Young Male Australian Workers. Journal of Financial Counseling and Planning, 20 (2), 5 - 12

Falahati, L., Paim, L., Ismail, M., Haron, S. A., \& Masud, J. (2011). Assessment of university students' financial management skills and educational needs. African Journal of Business Management, 5(15), 6085-6091.

Financial Sector Deepening, Kenya (2009). Annual Report. Supporting the Development of inclusive financial markets in Kenya.

Frasca, R. (2008). Personal Finance: An Integrated Planning Approach, 8th edition. Pearson/Prentice Hall, USA. Garman, E. T., \& Forgue, R. E. (1994). Personal finance (4thed.). Boston, MA: Houghton Mifflin

Garman, E. T., \& Forgue, R. (2008). Personal finance. Houghton Mifflin Company, USA

Garman, E. T., \& Forgue, R. (2011). Personal finance. Cengage Learning.

Godwin, D. D., \& Carroll, D. D. (1986). Financial management attitudes and behaviors of husbands and wives. 
Journal of Consumer Studies and Home Economics, 10, 47-55

Hanson, A. W., \& Cohen, J. B. (1954). Personal finance. Homewood, IL: Irwin.

Hilgert, M. A., Hogarth, J. M., \& Beverly, S. G. (2003). Household financial management: The connection between knowledge and behavior. Federal Reserve Bulletin, 89, 309-322

Hira, T. K. (2012). Promoting Sustainable Financial Behavior Internationally. Implications on Education and Research. Journal of Consumer Studies 36 (5), 502 - 507

Joo, S. (2008). Personal Financial Wellness; Handbook of Consumer Finances research. Springer, New York, USA

Joo, S., \& Grable, J. E. (2003). The Meaning and Measurements of Personal Finance Well ness. A Summary of professional Insights, Consumer Interests Annual, 40(1),

Joo, S. \& Grable, J. E (2004). An Exploratory Framework of the Determinants of Financial Satisfaction. Journal of Family and Economic Issues, 25(1), 162 - 171

Kapoor, J., Dlabay, L., \& Hughes, R. (2007). Personal finance (8th ed.). McGraw-Hill, New York

Kloeppinger-Todd, R., \& Sharma, M. (2010). Innovations in Rural and Agriculture Finance.Washington DC: International Food Policy Research Institute

Kwok, H., Milevisky, A., \& Robinson, C. (1994). Asset Allocation, Life Expectancy and

Shortfall. Financial Services Review 1994, 3(2), 109 - 126.

Lusardi, A., \& Tufano, P. (2015). Debt Literacy, Financial Experiences, and Overindebtedness. ,Journal of Pension Economics and Finance, 14(4), 329 - 365.

Malewos, K., \& Abiy, G. (2015). Personal Financial Management Capabilities Among Employees in Jimma Town, Southwest Ethiopia. European Journal of Contemporary Economics and Management. 2( 2), 29 - 35

Modigliani, F., \& Brumberg, R. (1954). Utility analysis and the consumption function: An interpretation of cross-section data. Franco Modigliani, 1, 388-436.

Muske G., Osteen. S., \& Jones, J. (2007). Financial Management Education: Its Role in Changing Behavior. Journal of Extension, 45 (3), 91 - 96

National Foundation for Credit Counseling (2007). Financial Literacy Survey, Research Associates International

Orodho, A. J. (2009). Essentials of Education and Social Sciences Research Methods; Masola Publishers Nairobi;

Porter, N. M., \& Garman, E. T. (1992). Testing a concept Testing a conceptual model of financial well-being. Financial Counseling and Planning, 4, 135-164.

Rajna, A., Ezat, S., Syed, J., \& Moshiri, (2011). Financial Management Attitudes and Practices among Medical Practitioners in Public and Private Medical Services in Malaysia. International Journal of Business and Management, $6(8), 105-112$

Reilly, F. K., \& Brown K. C. (2006). Investment Analysis and Portfolio Management. Thomson South West Publishers, USA

Sunitha, K. (2012). Financial Literacy, Financial Education. A road map to Personal Financial Well being and Prosperity. International Research Journal of Finance and Economics. 108, 132 - 143

World Bank Report (2016). Report on Kenya: Country Economic Memorandum. From Economic Growth to Jobs to Shared Prosperity.

Xiao, J. J., \& Dew, J. (2011). The financial management behavior scale: development and validation, Journal of Financial Counseling and Planning, 22(1) 49-53.

Yamane, T. (1967). Statistics. An introductory Analysis. 2nd Ed. New York. Harper and Row 